\title{
Sistem Informasi Data Stok Pallet Pada CV. Selang Surya Kencana
}

\author{
Pallet Stock Information System on CV. Selang Surya Kencana
}

\author{
Muhibun*1, Andri Firmansyah ${ }^{2}$, Muhammad Fatchan ${ }^{3}$, Irfan Afrianto ${ }^{4}$ \\ 1,2,3 Program Studi Teknik Informatika, Fakultas Teknik, Universitas Pelita Bangsa \\ e-mail: ${ }^{1}$ muhibun@mhs.pelitabangsa.ac.id, ${ }^{2}$ andrifirmansyah@pelitabangsa.ac.id, \\ ${ }^{3}$ fatchan@pelitabangsa.ac.id, ${ }^{4}$ irfanafrianto@pelittabangsa.ac.id,
}

\begin{abstract}
Abstrak
$C V$. Selang Surya Kencana adalah sebuah industri kecil dan menengah yang memproduksi beragam jenis kemasan kayu (Pallet kayu) sekitar JABODETABEK. Saat ini belum ada sistem informasi berbasis aplikasi yang dapat melakukan transaksi untuk mengetahui data keluar masuk produk jadi kemasan kayu (Pallet) karena informasi hanya di input menggunakan MS. Excel. Selain itu sering terjadi stok yang tidak sinkron dengan data aktual. Penyajian laporan order Pallet dan stok juga masih disajikan dengan waktu relatif lama, dan data customer order tidak dapat di mapping dengan baik. Hal tersebut menyebabkan tidak terintegrasinya pengolahan data, mulai dari data berapa jumlah produksi Pallet dalam periode tertentu sampai kepada berapa jumlah Pallet diorder sehingga data stok dapat disajikan dengan akurat. Selain itu pencarian data yang dibutuhkan memerlukan waktu yang lama, dan lambatnya proses pengolahan data membuat informasi yang dihasilkan kurang akurat dan aktual. Penelitian ini bertujuan untuk mempermudah proses transaksi pemesanan dan input hasil produksi. Dengan adanya sistem informasi ini dapat membantu dalam proses monitoring stok Pallet sehingga stok dapat terjaga. Sistem ini juga membantu megintegrasikan data mulai dari hasil produksi, pemesanan hingga ke persediaan stok Pallet secara otomatis. Selain itu pencarian data dan pengolahan data juga bisa di record dengan baik, sehingga output laporan dapat disajikan dengan cepat dan efisien.
\end{abstract}

Kata kunci: sistem informasi, data stok, otomatisasi proses, laporan

\begin{abstract}
Abstrack
$C V$. Selang Surya Kencana is a small and medium industry that produces various types of wood packaging (wooden pallets) around JABODETABEK. Currently, there is no information system that can record transactions because it is only input using MS. Excel. In addition, stocks that do not match the actual data often occur. Pallet and stock order report presentation is also still presented with a relatively long time, and customer order data cannot be mapped properly. This causes data processing to be not integrated, starting from the data on how many pallets are produced in a certain period to how many pallets are ordered so that stock data can be presented accurately. In addition, the search for the required data takes a long time, and the slow processing of the data makes the resulting information less accurate and actual. This study aims to simplify the process of ordering transactions and production inputs. With this information system, it can assist in the monitoring process of pallet stock so that the stock can be maintained. This system also helps to integrate data from production results to orders to inventory stock pallets automatically. In addition, data search and data processing can also be recorded properly, so that the report output can be presented quickly and efficiently.
\end{abstract}

Keyword: information systems, stock data, process automation, reports

\section{PENDAHULUAN}

Teknologi informasi berkembang begitu pesat dan memberikan engaruh luar biasa dalam kehidupan manusia. Saat ini manusia dapat melakukan segala aktivitas yang berhubungan dengan komputerisasi menjadi lebih efisien karena data dan informasi menjadi sangat cepat dan mudah untuk disajikan. Perkembangan teknologi informasi menjadi sebuah keharusan di dalam setiap instansi karena dengan kecanggihannya memberikan banyak kemudahan dan manfaat 
yang dapat menjadikan instansi tersebut semakin berkembang. Begitu juga dalam dunia industri yang mana semua proses harus berlangsung cepat dan mudah, sehingga memerlukan suatu penanganan komputerisasi yang handal.

CV. Selang Surya Kencana adalah sebuah industri kecil dan menengah yang memproduksi beragam jenis kemasan kayu (Pallet kayu) untuk kebutuhan industri sekitar Jabodetabek. CV Selang Surya Kencana mampu memproduksi 300 pcs kemasan kayu dalam sehari. Saat ini belum ada sistem informasi berbasis aplikasi yang dapat melakukan transaksi untuk mengetahui data keluar masuk produk jadi kemasan kayu (Pallet) karena informasi hanya di input menggunakan MS. Excel. Selain itu sering terjadi stok yang tidak sinkron dengan data aktual. Penyajian laporan order Pallet dan stok juga masih disajikan dengan waktu relatif lama, dan data customer order tidak dapat di mapping dengan baik. Cara manual tersebut menyebabkan tidak terintegrasinya pengolahan data, mulai dari data berapa jumlah produksi Pallet dalam periode tertentu sampai kepada berapa jumlah Pallet diorder sehingga data stok dapat disajikan dengan akurat. Selain itu tidak terdapat penyimpanan data yang terkomputerisasi sehingga membuat pencarian data yang dibutuhkan memerlukan waktu yang lama, dan lambatnya proses pengolahan data membuat informasi yang dihasilkan kurang akurat dan aktual. Berdasarkan hal tersebut maka penelitian ini bertujuan untuk menganalisis efektifitas proses order dan laporan stok yang sedang berjalan melalui suatu sistem sehingga dapat diketahui seberapa efektifnya implementasi sistem ini berjalan.

Beberapa penelitian terdahulu mengenai sistem informasi stok bahan baku sudah banyak dilakukan oleh beberapa peneliti lain, diantaranya adalah dengan adanya sistem informasi yang dibangun maka persediaan barang melalui metode FIFO dapat membantu mengkomputerisasikan aliran stok dengan baik sehingga tidak terjadi lagi human error, selain itu metode FIFO yang digunakan juga dapat membantu proses pengecekan data stok minimal secara lebih cepat, tepat dan dilakukan dimanapun[1]. Selain itu sistem informasi terhadap control stok untuk pendataan alat dan bahan kimia di laboratorium kimia STTIB ternyata dapat mempermudah section manager, staff lab, dan analisis dalam memonitoring barang yang ada di laboratorium mengingat proses pengadaan alat dan bahan kimia memerlukan waktu (leadTime) yang cukup lama [2]. Pembuatan sistem informasi stok juga ternyata dapat membantu untuk memberikan informasi dan soluasi saat dilakukannya pencatatan dan penilaian persediaan barang, selain itu sistem ini juga dapat mengetahui status pengiriman barang yang keluar serta mempermudah penyampaian informasi tentang stok update barang digudang tanpa harus menunggu akhir bulan di PT. Perkebunan Nusantara VIII[3]. Dalam pembuatan sistem informasi stok bahan baku atau pengelolaan barang ternyata dapat juga menerapkan beberapa konsep seperti Supply Chain Management (SCM) [4], Framework for the Applications (FAST) [5], First In First Out (FIFO) [6], Economic Order Quantity (EOQ) [7], Reorder Point (ROP) [8].

\section{METODE PENELITIAN}

Penelitian ini menggunakan dua jenis sumber data, yaitu data primer yang berasal dari data pemesanan dan data inputan hasil produk jadi yang sudah berjalan berdasarkan laporan manual yang dibuat selama ini. Sedangkan untuk data sekundernya peneliti ambil dari beberapa literatur dan informasi yang berasal dari luar. Untuk metode pengembangan sistem penulis menggunakan metode waterfall, yaitu:

a. Requirement

Pada tahapan ini akan dilakukan konsultasi dengan pengguna sistem yang sekaligus akan menilai dari proses bisnis yang sedang berjalan untuk pencatatam data pemesanan pallet dan stok. Selain itu dilakukan juga pengumpulan beberapa data untuk kebutuhan pengembangan sistem sehingga teridentifikasi beberapa kendala dalam mencari solusi terbaik yang dapat membantu mengatasi kelemahan sistem lama. 


\section{b. Design}

Pada tahapan ini akan dilakukan pembuatan arsitektur sistem yang akan dibuat berdasarkan persyaratan yang telah ditetapkan serta mengidentifikasi dan menggambarkan abstraksi dasar dari sistem perangkat lunak dan hubungannya.

c. Implementation

Pada tahapan ini hasil dari desain perangkat lunak akan direalisasikan sebagai suatu set program atau unit program. Dimana setiap unit akan diuji apakah sudah memenuhi spesifikasinya.

d. Verification

Dalam tahapan ini, setiap unit program akan diintegrasikan satu sama lain dan diuji sebagai satu sistem utuh untuk memastikan sistem sudah memenuhi persyaratan yang ada.

e. Maintenance

Dalam tahapan ini sistem akan mulai digunakan dan juga dilakukan pengembangan terhadap sistem seperti penambahan fitur dan fungsi baru.

Gambar 1 merupakan rangkuman terhadap proses metode waterfall yang dilakukan.

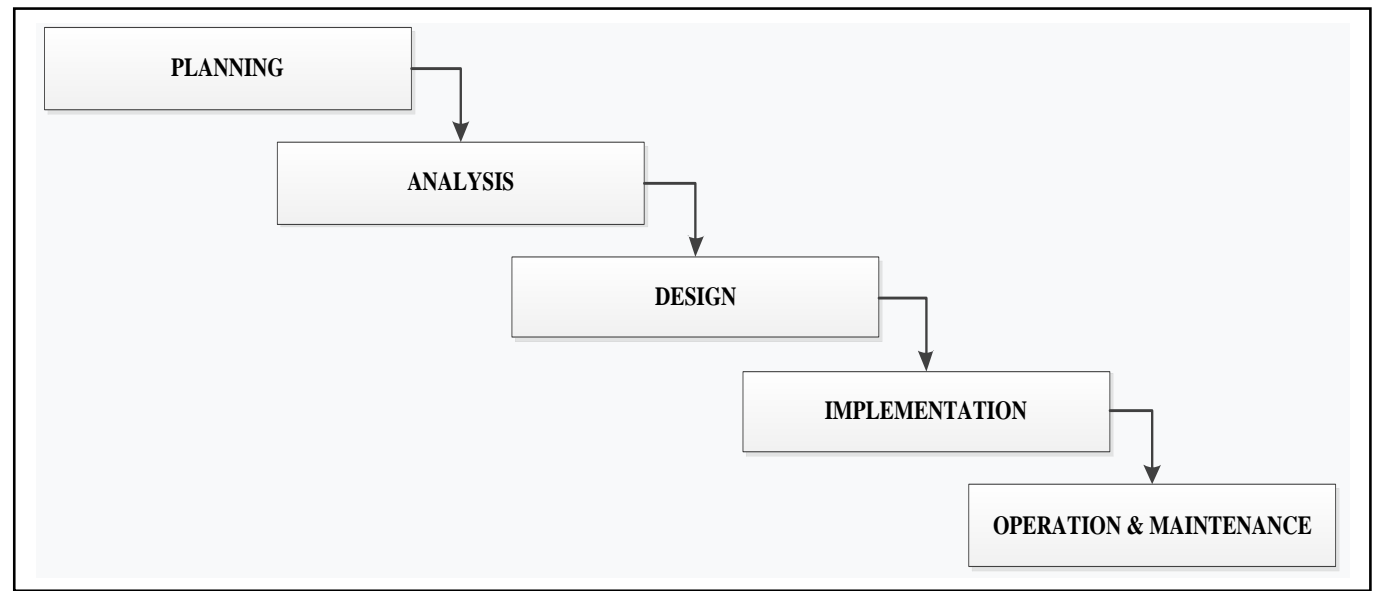

Gambar 1. Tahapan model pengembangan sistem

a. Identify

Selain itu tahapan analisis sistem yang dilakukan adalah sebagai berikut:

Dalam tahapan identifikasi permasalahan, ditemukan beberapa permasalahan seperti:

1) Belum adanya sistem yang dapat memonitoring stok pallet pada CV. Selang Surya Kencana karena sering terjadi data stok yang tidak sinkron dengan data actual.

2) Belum terintegrasinya data-data transaksi keluar masuk produk pallet sehingga untuk pendataan proses order dan stok belum teratur.

3) Tidak adanya proses penyimpanan data yang terstruktur dan berbasis database, sehingga proses pengolahan dan pencarian datanya menjadi lama.

b. Understand

Pada tahapan ini akan dilakukan pemahaman secara terinci bagaimana sistem yang ada akan beroperasi nantinya melalui observasi. Sistem baru yang akan dibuat harus dapat melakukan inputan terhadap data master pallet dan sejenisnya, input data customer, data transaksi pemesanan pallet dari customer sampai pada proses melihat data stok pallet. Sedangkan untuk laporan yang dibuat adalah laporan pemesanan pallet dan laporan stok pallet.

c. Analyze

Pada tahapan analyze akan dilakukan analisa terhadap sistem baru sebagai alternatif pemecahan masalah baik dari sisi kelamahan dan permasalahan[9]. Adapun beberapa kelemahan dan permasalahan dari sistem baru tersebut adalah: 
1) Sistem memerlukan resource cukup besar, hal ini berarti pemilik harus menyediakan server untuk menampung database

2) Sistem sangat bergantung pada jaringan LAN, sehingga apabila jaringan terputus maka sistem tidak dapat diakses.

\section{HASIL DAN PEMBAHASAN}

\section{Hasil penelitian}

Berdasarkan Analisa yang telah dilakukan, maka hirarki input proses dan output yang diusulkan terangkum pada Gambar 2.

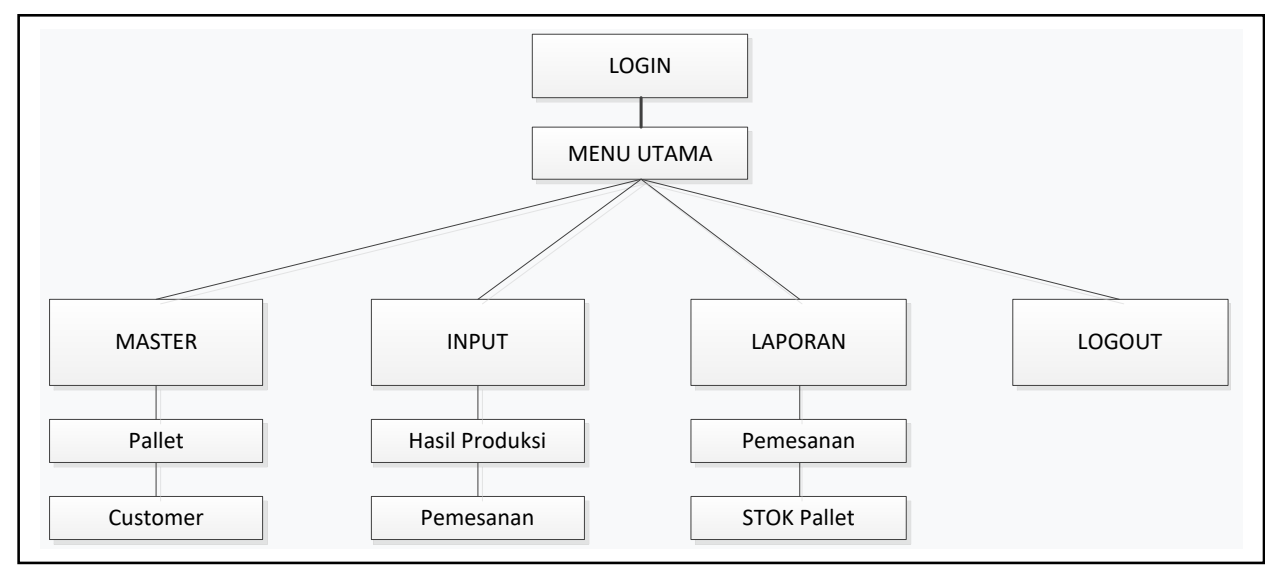

Gambar 2. HIPO susulan

Berdasarkan gambar 2, maka form login akan selalu ditampilkan terlebih dahulu saat sistem dijalankan. User yang digunakan dalam sistem adalah user bertingkat yang terdiri atas admin (pengelola sistem yang berhak atas input proses dan output dari sistem), staff gudang, dan manajer (melihat laporan baik laporan pemesanan dan laporan stok pallet). Penelitian ini akan menggunakan enam table untuk menampung data yang diperlukan, table tersebut diantaranya:

a. Customer $=\{@$ id_customer + nama_customer+ alamat + telp $\}$

b. Hasil_produksi $=\{@$ no_sistem + tanggal + no_produksi + id_pallet + qty $\}$

c. Pallet $=\{$ @id_pallet + nama_pallet + jenis + stok $\}$

d. Pemesanan= $\{@$ no_pemesanan + tanggal + no_po + id_customer $\}$

e. User_akses $=\{@$ kd_user + nama + username + password + hak $\}$

f. Pemesanan_detail $=\{$ no_pemesanan + id_pallet + qty $\}$

Masing-masing table tersebut akan memiliki form input dan output yang diperlukan. Master data dari table tersebut adalah table customer, pallet, dan user akses. Sedangkan table transaksinya adalah table hasil produksi, pemesanan serta pemesanan detail. Untuk memudahkan user dalam menggunakan sistem, maka desain input dan output akan kami samakan, tujuannya adalah untuk memudahkan mendapatkan feedback untuk sistem yang telah dibuat. Gambar 3 adalah desain dari input output yang dibuat. 

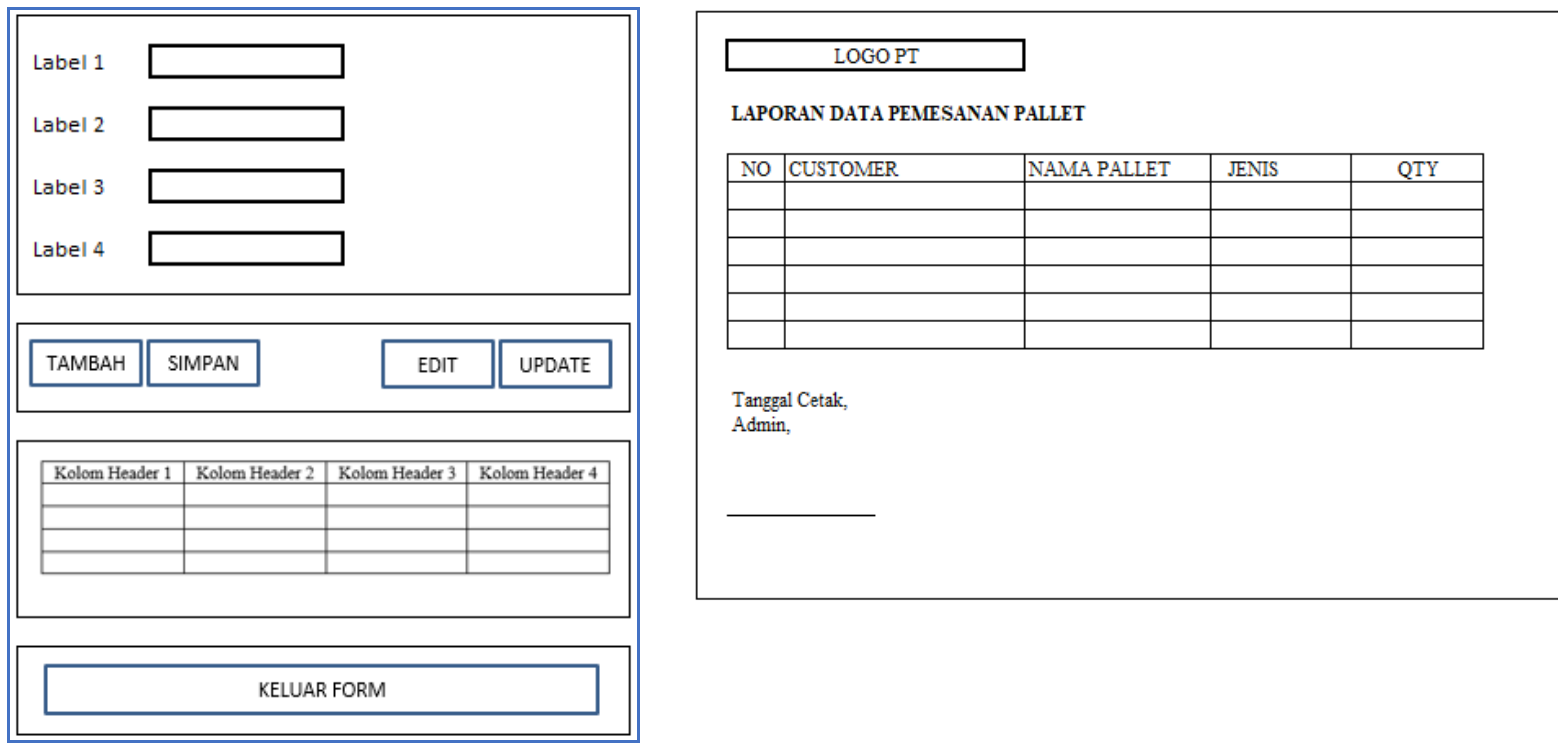

a

$\mathrm{b}$

Gambar 3. Desain input output sistem

\section{Hasil pengujian}

Pengujian perangkat lunak (software testing) merupakan suatu investigasi yang dilakukan untuk mendapatkan informasi mengenai kualitas dari sistem yang sedang diuji[10]. Pengujian perangkat lunak juga memberikan pandangan mengenai perangkat lunak secara obyektif dan independent, yang beramanfaat dalam operasional bisnis untuk memahami tingkat resiko pada implementasinya[11]. Tabe1 1 adalah rangkuman mengenai hasil pengujian yang telah dilakukan.

Tabel 1. Hasil pengujian

\begin{tabular}{|c|c|c|c|}
\hline \multicolumn{4}{|c|}{ Kasus dan Hasil Uji (Form Login dengan Data Normal) } \\
\hline Data Masukan & Data Diharapkan & Pengamatan & Kesimpulan \\
\hline Data Terdaftar & $\begin{array}{l}\text { Muncul pesan "Selamat datang } \\
\text { Admin...", lalu user akan masuk ke } \\
\text { tampilan MENU }\end{array}$ & $\begin{array}{l}\text { Muncul pesan "Selamat datang } \\
\text { Admin...", user dapat masuk ke } \\
\text { MENU UTAMA sesuai hak akses } \\
\text { masing-masing }\end{array}$ & $\begin{array}{l}\text { [x] Diterima } \\
\text { [ ] Ditolak }\end{array}$ \\
\hline \multicolumn{4}{|c|}{ Kasus dan Hasil Uji (Form Login dengan Data Salah) } \\
\hline Data Masukan & Data Diharapkan & Pengamatan & Kesimpulan \\
\hline Data nama tidak diisi & Muncul pesan "Login Gagal!” & Menampilkan pesan "Login Gagal!" & $\begin{array}{l}\text { [x] Diterima } \\
\text { [ ] Ditolak }\end{array}$ \\
\hline $\begin{array}{l}\text { Input username dan } \\
\text { password salah }\end{array}$ & $\begin{array}{l}\text { Muncul pesan "Maaf, Username atau } \\
\text { Password salah!" }\end{array}$ & $\begin{array}{l}\text { Menampilkan pesan "Maaf, } \\
\text { Username atau Password salah!" }\end{array}$ & $\begin{array}{l}\text { [x] Diterima } \\
\text { [ ] Ditolak }\end{array}$ \\
\hline \multicolumn{4}{|c|}{ Kasus dan Hasil Uji (Form Input Data Master dengan Data Normal) } \\
\hline Data Masukan & Data Diharapkan & Pengamatan & Kesimpulan \\
\hline $\begin{array}{l}\text { Input tidak lengkap } \\
\text { saat simpan }\end{array}$ & $\begin{array}{l}\text { Muncul pesan "Data Gagal Disimpan!" } \\
\text { pada Textbox saat klik SIMPAN }\end{array}$ & $\begin{array}{l}\text { Menampilkan pesan "Data Gagal } \\
\text { Disimpan!" }\end{array}$ & $\begin{array}{l}\text { [x] Diterima } \\
\text { [ ] Ditolak }\end{array}$ \\
\hline $\begin{array}{l}\text { Input tidak lengkap } \\
\text { saat update }\end{array}$ & $\begin{array}{l}\text { Muncul pesan "Data Gagal Disimpan!" } \\
\text { pada Textbox saat klik UPDATE }\end{array}$ & $\begin{array}{l}\text { Menampilkan pesan "Data Gagal } \\
\text { Disimpan!" }\end{array}$ & $\begin{array}{l}\text { [x] Diterima } \\
\text { [ ] Ditolak }\end{array}$ \\
\hline Data yang tersimpan & Data tampil di list tabel bawah form & Data tampil di list tabel bawah form & [x] Diterima \\
\hline
\end{tabular}




\begin{tabular}{|c|c|c|c|}
\hline $\begin{array}{l}\text { akan tampil di list } \\
\text { tabel bawah form } \\
\text { input atau di laporan }\end{array}$ & input atau di laporan & input atau di laporan & [ ] Ditolak \\
\hline \multicolumn{4}{|c|}{ Kasus dan Hasil Uji (Form Input Data Transaksi dengan Data Normal) } \\
\hline Data Masukan & Data Diharapkan & Pengamatan & Kesimpulan \\
\hline $\begin{array}{l}\text { Input tidak lengkap saat } \\
\text { simpan }\end{array}$ & $\begin{array}{l}\text { Muncul pesan "Data Gagal } \\
\text { Disimpan!" pada Textbox saat } \\
\text { klik SIMPAN }\end{array}$ & $\begin{array}{l}\text { Menampilkan pesan "Data Gagal } \\
\text { Disimpan!" }\end{array}$ & $\begin{array}{l}\text { [x] Diterima } \\
\text { [ ] Ditolak }\end{array}$ \\
\hline $\begin{array}{l}\text { Data yang tersimpan akan } \\
\text { tampil di list tabel bawah } \\
\text { form input atau di laporan }\end{array}$ & $\begin{array}{l}\text { Data tampil di list tabel bawah } \\
\text { form input atau di laporan }\end{array}$ & $\begin{array}{l}\text { Data tampil di list tabel bawah form } \\
\text { input atau di laporan }\end{array}$ & $\begin{array}{l}\text { [x] Diterima } \\
\text { [ ] Ditolak }\end{array}$ \\
\hline \multicolumn{4}{|c|}{ Kasus dan Hasil Uji (Rekap Laporan dengan Data Normal) } \\
\hline Data Masukan & Data Diharapkan & Pengamatan & Kesimpulan \\
\hline $\begin{array}{l}\text { Tanggal diisi sesuai periode } \\
\text { rekap }\end{array}$ & $\begin{array}{l}\text { Muncul data laporan rekap sesuai } \\
\text { periode yang diinput }\end{array}$ & $\begin{array}{l}\text { Menampilkan data laporan rekap } \\
\text { sesuai periode yang diinput }\end{array}$ & $\begin{array}{l}\text { [x] Diterima } \\
\text { [ ] Ditolak }\end{array}$ \\
\hline
\end{tabular}

Berdasarkan hasil pengujian yang telah dilakukan, maka dapat disimpulkan bahwa dengan adanya sistem ini maka semua proses transaksi yang dilakukan dari mulai pencatatan hasil produksi sampai pemesanan Pallet mudah dilakukan, selain itu proses pembuatan rekap laporan juga menjadi lebih mudah.

\section{KESIMPULAN}

Dari hasil penelitian dalam perancangan pembuatan sistem ini, maka dapat penulis simpulkan bahwa dengan adanya pengembangan sistem informasi pada CV. Selang Surya Kencana ini dapat membantu dalam proses monitoring stok Pallet sehingga persediaan aman untuk pemesanan Pallet bagi customer dapat terjaga. Selain itu sistem ini dapat membantu megintegrasikan data mulai dari hasil produksi, pemesanan hingga ke stok Pallet secara otomatis, sehingga tidak perlu lagi input data manual dan pencarian stok manual. Dengan sistem ini maka masalah-masalah yang berhubungan dengan informasi pencarian data dan pengolahan databisa di record dengan baik, sehingga output laporan dapat disajikan dengan cepat dan efisien.

\section{DAFTAR PUSTAKA}

[1] S. Wahyuning, "Sistem Informasi Akuntansi Persediaan Barang dengan Metode FIFO (Studi Kasus Pada De Kosmo Factory Outlet)," KOMPAK - J. Ilm. Komput. Akunt., vol. 8, no. 1, 2015.

[2] M. Muhammad Yusuf, I. Irianto, and S. Djalil, "Aplikasi Pengolahan Data Alat dan Bahan Kimia Laboratorium Kimia Sekolah Tinggi Teknologi Industri Bontang," Al Ulum Sains dan Teknol., vol. 4, no. 2, pp. 6-13, 2019, doi: 10.31602/ajst.v4i2.1973.

[3] A. Cahyadilani, W. Witanti, and P. N. Sabrina, "Perancangan Sistem Informasi Penjualan Teh pada PT. Perkebunan Nusantara VIII," Semin. Ris. Unggulan Nas. Inform. dan Komput. FTI UNSA, vol. 2, no. Bisnis Inelijen, pp. 13-18, 2019.

[4] T. S. Syamfithriani, T. F. Nugraha, and E. Darmawan, "Implementasi Supply Chain Management (SCM) Toko Alat dan Bahan Bangunan Berbasis Web (Studi Kasus : TB . Bojong Indah)," INFOTECH J., vol. 6, no. 2, pp. 44-50, 2020, doi: 10.31949/infotech.v6i2.840. 
[5] Tamodia 2013, "Rancang Bangun Sistem Informasi Persediaan Barang Berbasis Web Dengan Metode Fast (Framework For The Applications)," J. PILAR Nusa Mandiri, vol. Vol. 13, N, no. 2, pp. 261-266, 2017, [Online]. Available: http://ejournal.nusamandiri.ac.id/ejurnal/index.php/pilar/article/view/705.

[6] D. Meisak, "Analisis Dan Perancangan Sistem Informasi Persediaan Barang Menggunakan Metode FIFO Pada PT.Shukaku Jambi," Mediasisfo, vol. 11, no. 2, pp. 862-875, 2017.

[7] R. Rubhiyanti, I. Pratiwi, and F. Febryantahanuji, "Penerapan Metode Economic Order Quantity (EOQ) dalam Menganalisis Pengendalian Persediaan Padi," J. Akunt. Ekon., vol. 3, no. 2, pp. 12-23, 2018, doi: 10.29407/jae.v3i2.12504.

[8] S. B. Dyatmika and P. D. Krisnadewara, "Pengendalian Persediaan Obat Generik Dengan Metode Analisis Abc, Metode Economic Order Quantity (Eoq), Dan Reorder Point (Rop) Di Apotek Xyz Tahun 2017," MODUS Journals, vol. 30, no. 1, 2018, doi: 10.24002/modus.v30i1.1589.

[9] O. S. Bachri, "Sistem Informasi Pengolahan Data Nilai Murid Di SMA Negeri 4 Kota Cirebon," J. Digit, vol. 5, no. 1, pp. 24-33, 2015, doi: 10.51920/jd.v5i1.58.

[10] U. N. Sugandi, H. Harliana, and M. Mukidin, "Sistem Pakar Diagnosa Gizi Buruk Balita Dengan Certainty Factor," J. Ilm. Intech Informatioan Technol. J. UMUS, vol. 1, no. 1, pp. 75-85, 2019, doi: https://doi.org/10.46772/intech.v1i02.71.

[11] A. G. Puteri and R. M. H. Bhakti, "Penggunaan Certainty Factor Dalam Sistem Pakar Diagnosa Penyakit Jerawat," J. Ilm. Intech Inf. Technol. J. UMUS, vol. 1, no. 02, pp. 86-96, 2019, doi: 10.46772/intech.v1i02.72. 